\title{
Stressed and Happy? Investigating the Relationship Between Happiness and Perceived Stress
}

\author{
H. H. Schiffrin · D. Rezendes $\cdot$ S. K. Nelson
}

Published online: 16 October 2008

(C) Springer Science+Business Media B.V. 2008

\section{Erratum to: J Happiness Stud}

DOI 10.1007/s10902-008-9104-7

One of the authors' name, 'Rezendes, D.' in the article DOI 10.1007/s10902-008-9104-7 has been inadvertently left out. The appropriate citation for this article should be Schiffrin, H. H., Rezendes, D., \& Nelson, S. K. (2008). Stressed and happy? Investigating the relationship between happiness and perceived stress. Journal of Happiness Studies.

The online version of the original article can be found under doi:10.1007/s10902-008-9104-7.

H. H. Schiffrin $(\varangle) \cdot$ D. Rezendes $\cdot$ S. K. Nelson

University of Mary Washington, 1301 College Avenue, Fredericksburg, VA 22401, USA

e-mail: hschiffr@umw.edu 